\title{
Survey of Toxoplasma gondii, Neospora caninum and Sarcocystis neurona antibodies in wild red-tailed Amazon parrots (Amazona brasiliensis)
}

\author{
Pesquisa de anticorpos anti-Toxoplasma gondii, anti-Neospora caninum \\ e anti-Sarcocystis neurona em papagaios-de-cara-roxa (Amazona \\ brasiliensis) de vida livre
}

Ana Paula Sato1* (D), Frederico Fontanelli Vaz², Aline Luiza Konell1 ${ }^{1}$, Marilia de Oliveira Koch', Rafaela Furioso Ferreira ${ }^{3}$, Elenise Angelotti Bastos Sipinski ${ }^{4}$, Rosangela Locatelli Dittrich ${ }^{1}$

${ }^{1}$ Programa de Pós-graduação em Ciências Veterinárias, Universidade Federal do Paraná - UFPR, Curitiba, PR, Brasil 2Programa de Pós-graduação em Patologia Experimental e Comparada, Faculdade de Medicina Veterinária e Zootecnia, Universidade de São Paulo - USP, São Paulo, SP, Brasil

${ }^{3}$ Falculty of Veterinary Medicine, University of Zagreb, Croatia

${ }^{4}$ Bióloga na Sociedade de Pesquisa em Vida Selvagem e Educação Ambiental - SPVS, Curitiba, PR, Brasil

How to cite: Sato AP, Vaz FF, Konell AL, Koch MO, Ferreira RF, Sipinski EAB, Dittrich RL. Survey of Toxoplasma gondii, Neospora caninum and Sarcocystis neurona antibodies in wild red-tailed Amazon parrots (Amazona brasiliensis). Braz J Vet Parasitol 2020; 29(1): e017519. https://doi.org/10.1590/S1984-29612019107

\begin{abstract}
Toxoplasma gondii, Neospora caninum and Sarcocystis neurona are obligate intracellular parasites within the phylum Apicomplexa. The red-tailed Amazon parrot (Amazona brasiliensis) is a near-threatened species of psittacine that is endemic to the Atlantic Forest of Brazil and has been designated as a bioindicator because of its sensitivity to environmental qualitative status and changes. The aim of this study was to evaluate the presence of antibodies against $T$. gondii, N. caninum and S. neurona in wild red-tailed Amazon parrot nestlings on Rasa Island, Brazil. Blood samples were collected from 51 parrots and plasma samples were stored at $-20^{\circ} \mathrm{C}$ until immunofluorescence antibody tests (IFAT) were performed. Antigen slides were prepared using tachyzoites of $T$. gondii (RH strain) and, N. caninum (NC-1 strain) and using merozoites of S. neurona (SNR37 strain). Plasma samples were tested at initial dilutions of 1:16 for T. gondii, 1:50 for N. caninum and 1:5 for S. neurona. An anti-chicken antibody conjugated with FITC was used as a secondary antibody at 1:50 dilution. No antibodies for any of these three protozoa were found, thus suggesting that these wild red-tailed Amazon parrot nestlings had not been exposed to these parasites.
\end{abstract}

Keywords: Psittacine, protozoa, Apicomplexa, IFAT, wildlife conservation.

\section{Resumo}

Toxoplasma gondii, Neospora caninum e Sarcocystis neurona são protozoários intracelulares do filo Apicomplexa. O papagaio-de-cara-roxa (Amazona brasiliensis) é um psitacídeo endêmico da floresta atlântica, considerado uma espécie quase ameaçada de extinção e bioindicadora por sua sensibilidade às mudanças no ambiente. O objetivo do presente estudo foi detectar a presença de anticorpos contra T. gondii, N. caninum e S. neurona em filhotes de papagaios-de-cara-roxa (Amazona brasiliensis) de vida livre na Ilha Rasa, Brasil. Amostras de sangue foram coletadas de 51 papagaios e armazenadas $\mathrm{a}-20^{\circ} \mathrm{C}$ até a realização da Reação de Imunofluorescência Indireta (RIFI). As lâminas de RIFI com os antígenos, foram preparadas com taquizoítos de $T$. gondii (cepa RH) e $N$. caninum (cepa NC-1) e com merozoítos de S. neurona (cepa SNR37). Os plasmas foram diluídos em PBS (Ph 7,2) nas diluições 1:16 para $T$. gondii, 1:50 para $N$. caninum e 1:5 para $S$. neurona. O conjugado 
anti-IgG de galinhas marcado com fluoresceína (FITC) foi utilizado na diluição de 1:50. Não foram detectados anticorpos para os três protozoários nas amostras sugerindo que os filhotes de papagaios-de-cara-roxa não foram expostos aos protozoários.

Palavras-chave: Psitacídeos, protozoários, Apicomplexa, RIFI, conservação da vida selvagem.

\section{Introduction}

Wild birds are susceptible to a wide range of infectious and parasitic diseases. Monitoring these infections in birds may be an important element of effective environmental and public health surveillance systems, given that these birds can act as sentinels for environmental hazards and provide early warning of the need for intervention (Polley, 2005; Hamer et al., 2012).

The apicomplexans Toxoplasma gondii, Neospora caninum and Sarcocystis neurona are obligate intracellular parasites that infect many species of wild and domestic animals, including birds (Dubey et al., 2007; Dubey, 2010; Prakas \& Butkauskas, 2012).

Birds may become infected through ingestion of food and water contaminated with sporulated oocysts of $T$. gondii and N. caninum or with sporocysts of S. neurona, and they can also become infected through ingestion of cysts in infected tissues (Dubey, 2010; Dubey et al., 2016a).

$T$. gondii is the causative agent of toxoplasmosis, and birds can play an important epidemiological role in the transmission and maintenance of this zoonotic disease, whose definitive host is the cat family. In birds, the severity of the disease can range from subclinical to fatal acute infections. So far, only a few studies on the seroprevalence of T. gondii in birds within Psittaciformes have been carried out (Dubey, 2010; Zhang et al., 2014).

Neospora caninum is one of the major causative agents of abortion in cattle worldwide, being the canids its definitive hosts. Birds appear to be resistant to N. caninum infection, although its antibodies have been detected in blood and its DNA has been found in the tissues of wild birds (Donahoe et al., 2015; Rocchigiani et al., 2017). The role of birds in the epidemiological cycle of neosporosis remains unknown, but they can contribute towards parasite dissemination (De Barros et al., 2018).

There are more than 220 species of Sarcocystis, and birds can serve as definitive and intermediate hosts (Prakas \& Butkauskas, 2012). S. neurona is the causative agent of equine protozoal myeloencephalitis and the $S$. falcatula complex is highly pathogenic for birds of the orders Psittaciformes, Columbiformes and Passeriformes. Outbreaks of sarcocystosis have been reported, causing death among numerous avian species, particularly psittacines birds (Godoy et al., 2009; DUBEY et al., 2016b).

The red-tailed Amazon parrot (Amazona brasiliensis) inhabits the Atlantic Forest, along the coast of the Brazilian states of São Paulo, Santa Catarina and, predominantly, in Paraná. The coastal forest of this last state accounts for $75 \%$ of its population. This species has been designated as a bioindicator because of its sensitivity to environmental changes and qualitative status. In addition, the population of $A$. brasiliensis is dependent on conservation measures and is classified as near threatened on the IUCN Red List of Threatened Species (Sipinski, 2003; Carrillo \& Batista, 2007; IUCN, 2017).

In Paraná, the parrots can live close to some human communities, which very often own domestic animals e.g. chicken, ducks, geese, horses, cats and dogs, being some of them common hosts of $T$. gondii and N. caninum (Locatelli-Dittrich et al., 2006; Dubey, 2010). In addition, one the main A. brasiliensis nestlings' predators are the Brazilian common opossum (Didelphis aurita) (Sipinski, 2003), and there are evidence of Didelphis species acting as host of Sarcocystis sp. (Gondim et al., 2017; Gallo et al., 2018).

Because of the rather limited geographical range of $A$. brasiliensis, its small population, its likely susceptibility to the above-mentioned pathogens, whose epidemiology that so far has not been widely researched in Psittaciformes, the aim of this study was to 
evaluate the presence of antibodies against $T$. gondii, N. caninum and S. neurona in wild red-tailed Amazon parrot nestlings from Rasa Island, Paraná, Brazil in an attempt to address the risks to the population and to better understand the patterns of the diseases in the nature.

\section{Materials and Methods}

This study was approved by the Animal Use Ethics Committee of the Agricultural Sciences Campus of the Federal University of the State of Paraná, in southern Brazil (protocol number 050/2013), and through the SISBIO federal authorization system (number 41035-1). The study was conducted on Rasa Island, which is located in the Environmental Protection Area (EPA) of Guaraqueçaba. This is a protected area of Atlantic forest located in Paraná, Brazil ( $25^{\circ} 15^{\prime}$ to $25^{\circ} 30^{\prime} \mathrm{S}$ and $48^{\circ} 20^{\prime}$ to $48^{\circ} 30^{\prime} \mathrm{W}$ ), which is subject to constant monitoring by the Society of Wildlife Research and Environmental Education (SPVS) (SPVS, 1992; Carrillo \& Batista, 2007). The estimated resident human population is in excess of 400 (Sipinski, 2003). The EPA consists of estuaries, islands, mangrove forests, plains, mountains and plateaus, totaling approximately 314,000 hectares (SPVS, 1992; Carrillo \& Batista, 2007).

Sample collection was carried out over a single breeding season (December 2013 to January 2014), in five field expeditions, concomitantly with the monitoring of nestlings by SPVS. Natural and artificial nests (made of wood or PVC) were reached using climbing equipment. Blood samples were collected from $51 \mathrm{~A}$. brasiliensis nestlings with an estimated age of over 26 days. The birds were taken from the nest for clinical examination and carefully sampled.

The blood samples were collected from these nestlings 'superficial ulnar vein, previously disinfected with $70 \%$ alcohol, in $1-\mathrm{mL}$ syringes with $20 \times 0.55 \mathrm{~mm}$ needles pretreated with $1000 \mathrm{IU}$ of sodium heparin. A maximum of $1 \mathrm{~mL}$ of whole blood was collected. All samples were kept in tubes on ice and were transported to the Veterinary Clinical Pathology Laboratory of the Federal University of Parana (Curitiba, Paraná, Brazil), within 24 hours. The tubes were centrifuged for $5 \mathrm{~min}$ at $1.708 \mathrm{~g}$ to obtain plasma and, were stored frozen at $-20^{\circ} \mathrm{C}$ until analysis.

Detection of specific $T$. gondii, S. neurona and N. caninum antibodies were carried out by an immunofluorescent antibody test (IFAT) as previously described by LocatelliDittrich et al. (2006) and Moré et al. (2008), with some modifications. Antigen slides were prepared using tachyzoites of $T$. gondii (RH strain) and, N. caninum (NC-1 strain), and using merozoites of $S$. neurona (SNR37 strain). Plasma samples were tested at initial dilutions of 1:16 for T. gondii (Camillo et al., 2015), 1:50 for N. caninum (Molina-López et al., 2012), and 1:5 for S. neurona (Cray et al., 2005). An anti-chicken IgG antibody conjugated with FITC (Sigma, USA) was used as a secondary antibody at 1:50 dilution. Slides were mounted using carbonate-buffered glycerin $(\mathrm{pH} 9.5)$ and coverslips and were then read in an epifluorescence microscope (Olympus, Japan). A positive serum sample obtained from a bird of prey was used as a positive control for $T$. gondii and for Sarcocystis sp. Dog sera positive was used to validate a positive control for $N$. caninum. A negative serum sample obtained from a bird of prey was used as a negative control for these three protozoans. Only bright fluorescence of the entire tachyzoite and merozoite surface was considered to be a positive result.

\section{Results and Discussion}

No antibodies to T. gondii, N. caninum or S. neurona were found in any of the wild redtailed Amazon parrot nestlings that were sampled.

A number of factors may have contributed to the absence of seropositivity, such as the birds' age, environment, behavior or diet. Wild nestlings may be less exposed to 
infection than adult birds, since they stay in the nest and probably do not have contact with contactants and pathogens. However, parents can carry contaminants to the nest and contribute to transmission of infections agents to the nestlings (Ritchie, 1995; Dubey, 2010). Predators of eggs and birds, such as opossums, toucans and roadside hawks (Sipinski, 2003) could also possibly carry fecal parasitic forms to the nest.

Few seroepidemiological studies on $T$. gondii and $N$. caninum in wild birds in Brazil have been conducted (Andrade et al., 2016; De Barros et al., 2018). These few studies have mainly reported findings of anti- $T$. gondii antibodies in serum from captive birds, using the modified agglutination test (MAT). Marietto-Gonçalves et al. (2013) used MAT to investigate anti- $T$. gondii antibodies (IgY) in serum from 71 adult blue-fronted Amazon parrots (Amazona aestiva) that had been rescued from illegal trade, and found a seropositivity rate of $9.8 \%$, in contrast to the findings from the present study. Zhang et al. (2014) used MAT to search for T. gondii antibodies in 311 birds, including budgerigars (Melopsittacus undulatus), lovebirds (Agapornis sp.) and cockatiels (Nymphicus hollandicus) that were kept as pets in China, and revealed seroprevalence of $8.36 \%$ (26 birds).

MAT was also used in a study carried out in Brazil, in the state of Paraiba and Bahia, involving 222 wild birds of 67 different species including psittacines, in which anti-T. gondii antibodies were detected in serum from only $1.3 \%$ of the birds. This suggested that the prevalence of $T$. gondii was low in these birds, as also observed in the present study (Andrade et al., 2016).

Occurrences of $N$. caninum were evaluated in 294 wild birds, including 102 adult psittacines birds, and no antibodies for $N$. caninum were detected. The absence of seropositive birds was explained by the fact that these birds appeared to have a sudden seroconversion of IgY (IgG) and a brief detection window (Mineo et al., 2011).

Some psittacine species have been reported to be susceptible intermediate hosts for Sarcocystis falcatula in situations of both natural and experimental infection (Maier et al., 2015). Antibodies against Sarcocystis falcatula have been documented in psittacines, mainly associated with subclinical and chronic infections (Cray et al., 2005).

The study was conducted in Rasa Island, Environmental Protection Area of Guaraqueçaba-PR. Although it is a protected area, there are houses nearby and contact between humans, cats and dogs with free-living animals. The presence of definitive hosts of $T$. gondii and $N$. caninum in the study area suggests the occurrence of oocysts in the environment but may not be associated with the chance of parrots be infected, as these birds rarely come down to feed on the ground. There are no data on the $T$. gondii and $N$. caninum seropositivity in cats and dogs in Rasa Island. Most of the serologic surveys in the state of Paraná were conducted in domestic animals and distant from the study area (Dubey et al., 2012; Cerqueira-Cézar et al., 2017; Konell et al., 2019).

In conclusion, the results from this study revealed that antibodies for $T$. gondii, N. caninum and S. neurona were absent from wild A. brasiliensis nestlings in Rasa Island, Paraná, Brazil. It is possible that these birds had not yet been exposed to the protozoa. Further studies are needed to evaluate the epidemiological role of psittacine birds (particularly adults) in the life cycle of these protozoa.

\section{Acknowledgements}

We are grateful to the Society for Wildlife Research and Environmental Education (SPVS) for logistics and technical support in Guaraqueçaba and for their efforts to conserve the red-tailed Amazon parrot.

\section{References}

Andrade LHM, Lugarini C, Oliveira RAS, Silva LTR, Marvullo MFV, Garcia JE, et al. Ocorrência de anticorpos anti-Toxoplasma gondii em aves silvestres de três unidades de conservação federais 
da Paraíba e da Bahia. Pesq Vet Bras 2016; 36(2): 103-107. http://dx.doi.org/10.1590/S0100736X2016000200007.

Camillo G, Cadore GC, Ferreira MST, Braünig P, Maciel JF, Pivoto FL, et al. Toxoplasma gondii and Neospora caninum antibodies in backyard chickens in Rio Grande do Sul, Brazil. Rev Bras Cienc Avic 2015; 17(2): 263-265. http://dx.doi.org/10.1590/1516-635x1702263-265.

Carrillo AC, Batista DB. A conservação do papagaio-da-cara-roxa (Amazona brasiliensis) no estado do Paraná - uma experiência de educação ambiental no ensino formal. Rev Arvore 2007; 31(1): 113122. http://dx.doi.org/10.1590/S0100-67622007000100013.

Cerqueira-Cézar CK, Calero-Bernal R, Dubey JP, Gennari SM. All about neosporosis in Brazil. Rev Bras Parasitol Vet 2017; 26(3): 253-279. http://dx.doi.org/10.1590/s1984-29612017045. PMid:28876360.

Cray C, Zielezienski-Roberts K, Bonda M, Stevenson R, Ness R, Clubb S, et al. Serologic diagnosis of Sarcocystosis in Psittacine birds: 16 cases. J Avian Med Surg 2005; 19(3): 208-215. http://dx.doi.org/10.1647/1082-6742(2005)019[0208:SDOSIP]2.0.CO;2.

De Barros LD, Miura AC, Minutti AF, Vidotto O, Garcia JL. Neospora caninum in birds: A review. Parasitol Int 2018; 67(4): 397-402. http://dx.doi.org/10.1016/j.parint.2018.03.009. PMid:29614327.

Donahoe SL, Lindsay SA, Krockenberger M, Phalen D, Šlapeta J. A review of neosporosis and pathologic findings of Neospora caninum infection in wildlife. Int J Parasitol Parasites Wildl 2015; 4(2): 216-238. http://dx.doi.org/10.1016/j.ijppaw.2015.04.002. PMid:25973393.

Dubey JP, Calero-Bernal R, Rosenthal BM, Speer CA, Fayer R. General biology. In: Dubey JP, CaleroBernal R, Rosenthal BM, Speer CA, Fayer R. Sarcocystosis of animals and humans. 2nd ed. Boca Raton: CRC Press; 2016a. p. 1-109.

Dubey JP, Calero-Bernal R, Rosenthal BM, Speer CA, Fayer R. Sarcocystosis in Other avian Species. In: Dubey JP, Calero-Bernal R, Rosenthal BM, Speer CA, Fayer R. Sarcocystosis of animals and humans. 2nd ed. Boca Raton: CRC Press; 2016b. p. 281-292.

Dubey JP, Lago EG, Gennari SM, Su C, Jones JL. Toxoplasmosis in humans and animals in Brazil: high prevalence, high burden of disease, and epidemiology. Parasitology 2012; 139(11): 1375-1424. http://dx.doi.org/10.1017/S0031182012000765. PMid:22776427.

Dubey JP, Schares G, Ortega-Mora L. Epidemiology and control of neosporosis and Neospora caninum. Clin Microbiol Rev 2007; 20(2): 323-367. http://dx.doi.org/10.1128/CMR.00031-06. PMid:17428888.

Dubey JP. Toxoplasmosis of animals and humans. Boca Raton: CRC Press; 2010.

Gallo SSM, Lindsay DS, Ederli NB, Matteoli FP, Venancio TM, Oliveira FCR. Identification of opossums Didelphis aurita (Wied-Neuweid, 1826) as a definitive host of Sarcocystis falcatula-like sporocysts. Parasitol Res 2018; 117(1): 213-223. http://dx.doi.org/10.1007/s00436-017-5695-4. PMid:29192336.

Godoy SN, De Paula CD, Cubas ZS, Matushima ER, Catão-Dias JL. Occurrence of Sarcocystis falcatula in Captive Psittacine Birds in Brazil. J Avian Med Surg 2009; 23(1): 18-23. http://dx.doi.org/10.1647/2008-006R.1. PMid:19530402.

Gondim LSQ, Jesus RF, Ribeiro-Andrade M, Silva JCR, Siqueira DB, Marvulo MFV, et al. Sarcocystis neurona and Neospora caninum in Brazilian opossums (Didelphis spp.): molecular investigation and in vitro isolation of Sarcocystis spp. Vet Parasitol 2017; 243: 192-198. http://dx.doi.org/10.1016/j.vetpar.2017.07.002. PMid:28807293.

Hamer A, Lehrer E, Magle B. Wild birds as sentinels for multiple zoonotic pathogens along an urban to rural gradient in greater Chicago, Illinois S. Zoonoses Public Health 2012; 59(5): 355-364. http://dx.doi.org/10.1111/j.1863-2378.2012.01462.x. PMid:22353581.

International Union for Conservation of Nature - IUCN. Red List of Threatened Species. Version 2017-3 [online]. Cambridge: IUCN; 2017 [cited 2018 May 20]. Available from http://www.iucnredlist.org

Konell AL, Sato AP, Stival M, Malaguini NP, Anjos A, Ferreira RF, et al. Serosurvey of Toxoplasma gondii, Sarcocystis sp. and Neospora caninum in geese (Anser sp.) from urban parks and captivity. Rev Bras Parasitol Vet 2019; 28(2): 221-228. http://dx.doi.org/10.1590/s1984-29612019042. PMid:31271639. 
Locatelli-Dittrich R, Dittrich JR, Richartz RR, Gasino Joineau ME, Antunes J, Pinckney RD, et al. Investigation of Neospora sp. and Toxoplasma gondii antibodies in mares and in precolostral foals from Parana State, Southern Brazil. Vet Parasitol 2006; 135(3-4): 215-221. http://dx.doi.org/10.1016/j.vetpar.2005.10.010. PMid:16289863.

Maier K, Olias P, Enderlein D, Klopfleisch R, Mayr SL, Gruber AD, et al. Parasite distribution and earlystage encephalitis in Sarcocystis calchasi infections in domestic pigeons (Columba livia f. domestica). Avian Pathol 2015; 44(1): 5-12. http://dx.doi.org/10.1080/03079457.2014.978263. PMid:25338141.

Marietto-Gonçalves GA, Almeida SM, Camossi LG, Langoni H, Andreatti Filho RL. Avaliação sorológica de Parainfluenzavirus Tipo 1, Salmonella spp., Mycoplasma spp. e Toxoplasma gondii em aves silvestres. Cienc Anim Bras 2013; 14(4): 473-480. http://dx.doi.org/10.5216/cab.v14i4.16576.

Mineo TW, Carrasco AOT, Raso TF, Werther K, Pinto AA, Machado RZ. Survey for natural Neospora caninum infection in wild and captive birds. Vet Parasitol 2011; 182(2-4): 352-355. http://dx.doi.org/10.1016/j.vetpar.2011.05.022. PMid:21680099.

Molina-López R, Cabezón O, Pabón M, Darwich L, Obón E, Lopez-Gatius F, et al. High seroprevalence of Toxoplasma gondii and Neospora caninum in the Common raven (Corvus corax) in the Northeast of Spain. Res Vet Sci 2012; 93(1): 300-302. http://dx.doi.org/10.1016/j.rvsc.2011.05.011. PMid:21645913.

Moré G, Basso W, Bacigalupe D, Venturini MC, Venturini L. Diagnosis of Sarcocystis cruzi, Neospora caninum, and Toxoplasma gondii infections in cattle. Parasitol Res 2008; 102(4): 671-675. http://dx.doi.org/10.1007/s00436-007-0810-6. PMid:18066600.

Polley L. Navigating parasite webs and parasite flow: emerging and re-emerging parasitic zoonoses of wildlife origin. Int J Parasitol 2005; 35(11-12): 1279-1294. http://dx.doi.org/10.1016/j.ijpara.2005.07.003. PMid:16168994.

Prakas P, Butkauskas D. Protozoan parasites from genus Sarcocystis and their investigations in Lithuania. Ekologija (Liet Moksl Akad) 2012; 58(1): 45-58. http://dx.doi.org/10.6001/ekologija.v58i1.2349.

Ritchie BW. Avian viruses: function and control. Lake Worth: Wingers Publishing Press; 1995.

Rocchigiani G, Poli A, Nardoni S, Papini R, Mancianti F. Neospora caninum in Wild Waterfowl: Occurrence of Parasite DNA and Low Antibody Titers. J Parasitol 2017; 103(1): 142-145. http://dx.doi.org/10.1645/16-34. PMid:27805842.

Sipinski EAB. O papagaio-de-cara-roxa (Amazona brasilienses) na ilha Rasa, PR - aspectos ecológicos e reprodutivos e relação com o ambiente [dissertação]. Curitiba: Universidade Federal do Paraná; 2003.

Sociedade de Pesquisa em Vida Selvagem e Educação Ambiental - SPVS. Plano integrado de conservação para a região de Guaraqueçaba, Paraná, Brasil [online]. Curitiba: SPVS; 1992 [cited 2019 April 05]. Available from: http://www.spvs.org.br/wpcontent/uploads/downloads/2018/01/Planolntegrado.pdf

Zhang X, Zhang N, Tian W, Zhou D, Xu Y, Zhu X. First report of Toxoplasma gondii seroprevalence in pet parrots in china. Vector Borne Zoonotic Dis 2014; 14(6): 394-398. http://dx.doi.org/10.1089/vbz.2013.1522. PMid:24866015. 